\title{
Forage Yield Stability of some Egyptian Clover Genotypes (Trifolium alexandrinum L.) under Different Sowing Dates
}

\author{
Bakheit, B.R.; E.A. Teama; Asmaa, A. Mohamed and F.M. Fathy
}

Agronomy Department, Faculty of Agriculture, Assiut University, Assiut, Egypt

Received on: 12/2/2017

Accepted for publication on: 19/3/2017

\begin{abstract}
This investigation was carried out to study the effect of temperature resulting from different planting dates during the stage of vegetative growth and the effect of genotypes $\mathrm{x}$ environment interaction on forage yield and its components in some varieties of berseem clover (Trifolium alexandrinum L.). A set of six varieties (Serw-1, Gemmeiza-1, Giza-6, Sakha-4, Helally and Local variety) were sown on four planting dates (September $15^{\text {th }}$, October $15^{\text {th }}$, November $15^{\text {th }}$ and December $15^{\text {th }}$ ) in randomized complete block design with four replicates in experimental farm of Assiut University during 2014/2015 and 2015/2016 seasons. Three cuts were taken after 70, 110, 145 days from sowing. The results showed that the planting dates and varieties had a significant differences for plant height leaf/stem ratio, seasonal fresh and dry forage yields in both seasons and over the two seasons. Also, the tallest plant height was obtained from the plants sown on $15^{\text {th }}$ October in both seasons. Serw-1 variety significantly gave the tallest plant height over planting dates. Moreover, the highest leaf/stem ratio was obtained from the planting date at September $15^{\text {th }}$ in both seasons. Otherwise, leaf/stem ratio decreased gradually and reached to the minimum value at the December $15^{\text {th }}$ in both seasons. Local variety gave the highest leaf/stem ratio.

The seasonal fresh forage yield significant decreased as planting date was delayed. Helally variety produced the highest seasonal fresh forage yield over the two seasons. Meanwhile, the seasonal dry forage yield increased as planting date was delayed. No significant differences were noticed in seasonal dry forage yield among commercial varieties (Serw-1, Gemmeiza-1, Giza-6, Sakha-4 and Helally). In the same the trend, the environments, varieties and their interaction were significant for plant height, leaf/stem ratio and seasonal dry forage yield.

Finally, the stability analysis revealed that the average stability region involved Gemmeiza-1, Giza-6, Local variety and Serw-1 varieties for plant height, Gemmeiza-1, Local variety and Serw-1 varieties for leaf/stem ratio and Gemmeiza-1 and Helally varieties for seasonal dry forage yield.
\end{abstract}

Keywords: Egyptian clover, Trifolium alexandrinum L., planting dates, stability, genotype $x$ environment interaction, forage yield.

\section{Introduction}

Egyptian clover or berseem, Trifolium alexandrinum $\mathrm{L}$. is the main and oldest cultivated winter forage leguminous crop in Egypt. It is basic for realizing a sustainable cropping system in Egypt. It occupies about one fourth of the cultivated area with average of 1.63 million feddan (B.A.S., 2014/2015). Also, it is well adapted to semi-arid condition and grown in India, Pakistan, Turkey and Mediterranean region. Egyptian clover is high nutritional quality for animal feed also contributes to soil fertility and improved physical and chemical characteristics (Graves et $a l ., 1996)$. Thereby it is called king of forages in Egypt. 
Current changes in the climatic conditions towards warming especially in Egypt are expected to prolong the spring and summer seasons and shortens the winter season and extended in temperature during which Egyptian clover in grown. Thus, it was throught desirable to change the planting date of Egyptian clover to avoid the high or low temperature effects at the beginning of the full season, a practice which was studied by some workers.

Forage yield and its components is often influenced by weather condition at the reproductive period. Ramadan et al. (1994) reported that the first ten days of October are the best period for sowing all cultivars for forage yield. Usmani-Khalil et al. (2001) found sowing berseem clover on the $15^{\text {th }}$ November gaves more fresh forage yield. El-Zanaty (2005) revealed that the highest fresh and dry forage yields were significantly obtained by planting on the first of November. Also, Kandil and Sharief (2016) stated that early planting on Mid-September maximize forage production per unit area and enhancing forage quality.

Variation in weather conditions at various stages of plant development may affect the differential response of genotypes to environments. Identification of weather variables associated with the genotype $\mathrm{x}$ environment interaction is thus important in understanding the nature and patterns of these interactions (Saeed and Francis, 1984). It is important to determine how the temperature affects forage yield components and define the nature of their associations with forage yield in Egyptian clover. Such information may be used to plan efficient breeding programs to develop more productive varieties or to improve crop management which might favour forage production as an economically competitive enterprise. Under the changes in climatic condi- tions, it is important issue to determine the stability of the Egyptian clover varieties. The genotypic stability as estimated by Tai (1971) is a fit analysis to propose the stability of these varieties performance.

The objective of this study was undertaken to determine the influence of temperature conditions resulting from different sowing dates on the forage yield and its components, as well as study the stability of forage yield of berseem varieties when tested under different environments (planting dates $\mathrm{x}$ seasons).

\section{Materials and Methods}

The present study was carried out at the Agricultural Experimental Farm, Assiut University, Egypt, during two successive growing seasons of 2014/2015 and 2015/2016 to study the effect of temperature conditions resulting from different sowing dates on forage yield and its components of six berseem varieties. The some physical and chemical properties of the experimental soil are sand $(26 \%)$, silt $(24 \%)$, clay $(50.0 \%)$, soil $\mathrm{pH}$ (7.8), organic matter $(1.6 \%)$, total $\mathrm{N}$ $(0.1 \%)$ and $\mathrm{CaCO}_{3}(1.2 \%)$.

The genetic materials for this study included five varieties obtained from the Forage Crop Department, ARC, Ministry of Agriculture, Giza, Egypt, beside the local variety from Assiut farmers. The names of these varieties are Serw-1, Gemmeiza-1, Giza-6, Sakha-4, Helally and Local variety.

Four sowing dates of $15^{\text {th }}$ September, $15^{\text {th }}$ October, $15^{\text {th }}$ November and $15^{\text {th }}$ December were used for the six berseem varieties in randomized complete block design with four replications for each planting date in both seasons. Plot size was $10.5 \mathrm{~m}^{2}$. Berseem seed were sown by hand at the rate of $6.0 \mathrm{~g} / \mathrm{m}^{2}(25 \mathrm{~kg} / \mathrm{fed}$. $)$. Phosphorus was applied at the level of $37.5 \mathrm{~g} \mathrm{P}_{2} \mathrm{O}_{5} /$ plot in the form of calcium super phosphate $\left(\mathrm{P}_{2} \mathrm{O}_{5} \quad 15.5 \%\right)$ before seeding. All cultural practices 
were maintained at optimum level for maximum berseem productivity. Three cuts were taken from each planting date at 70, 110 and 145 days after sowing at 70, 40 and 35 days intervals, respectively.

\section{Data recorded:}

The following traits were recorded at the time of each cut for each planting date.

1- Plant height $(\mathrm{cm})$ determined from soil surface until the upper tip of plant. The average of five measurements for each plot at each cut, then average of three cuts were calculated.

2- Leaves/stems ratio (fresh weight). A sample of fresh forage in each plot (about $200 \mathrm{~g}$ ) was hand separated to leaves and stems. Each component was weighed immediately to estimate the ratio, then mean of three cuts were taken.
3- Fresh forage yield (kg/plot) determined by hand clipping of each plot and total of three cuts were taken for each planting date.

4- Dry forage yield (kg/plot) estimated by using, green forage yield of each plot $x$ mean dry matter percentage, where dry matter percentage was determined from random samples of $150 \mathrm{~g}$ from each plot at each cut, after drying in an oven at $70^{\circ} \mathrm{C}$ until weight constancy. The total of three cuts were taken.

Climatic data during the study period including maximum and minimum daily temperature measured from planting date to the third cut in each season and planting date are presented in Table 1.

Table 1. Summary of the daily temperature during the period of berseem clover growth in 2014/2015 and 2015/2016 seasons.

\begin{tabular}{|c|c|c|c|c|c|c|c|c|c|c|}
\hline \multirow{3}{*}{ Month } & \multicolumn{4}{|c|}{ Average temperature } & \multicolumn{4}{|c|}{ Relative humidity } & \multirow{2}{*}{\multicolumn{2}{|c|}{ Photoperiod }} \\
\hline & \multicolumn{2}{|c|}{ Maximum } & \multicolumn{2}{|c|}{ Minimum } & \multicolumn{2}{|c|}{ Maximum } & \multicolumn{2}{|c|}{ Minimum } & & \\
\hline & 2014/2015 & $2015 / 2016$ & $2014 / 2015$ & $2015 / 2016$ & $014 / 2015$ & $2015 / 2016$ & $2014 / 2015$ & 2015/2016 & $2014 / 2015$ & $2015 / 2016$ \\
\hline 15-30 September & 38.1 & 39.4 & 21.5 & 21.3 & 54.5 & 56.4 & 16.21 & 16.4 & $12: 09: 28 \mathrm{pm}$ & $2: 09: 52 \mathrm{pm}$ \\
\hline 1-15 October & 33.9 & 36.6 & 18.3 & 20.6 & 59.4 & 73.8 & 17.4 & 22.73 & $11: 45: 28$ am & $52 \mathrm{am}$ \\
\hline 16-31 October & 32.2 & 33.5 & 15.8 & 19.0 & 59.6 & 77.8 & 19.12 & 26.2 & $11: 21: 41 \mathrm{am}$ & $11: 22: 11 \mathrm{am}$ \\
\hline 1-15 Noven & 30.1 & 28.3 & 14.0 & 14.5 & 67.66 & 84.3 & 20.6 & 33.6 & $10: 59: 56 \mathrm{am}$ & 11:00:16 am \\
\hline 16-30 Nov & 6.0 & 27.5 & 11.7 & 12.0 & 72.8 & 84.0 & 29.6 & 29.2 & $10: 42: 36 \mathrm{am}$ & $\mathrm{am}$ \\
\hline $1-15 \mathrm{D}$ & 0 & .7 & 10.7 & 8.3 & 8.1 & 86.8 & 26.0 & 33.0 & $\mathrm{n}$ & \\
\hline $16-31 \mathrm{De}$ & 23.1 & 21.6 & 8.4 & 6.9 & 73.6 & 90.2 & 28.7 & 31.3 & 10:27:11 am & $3 \mathrm{am}$ \\
\hline 1-15 Janu & 18.3 & 21.5 & 4.5 & 6.2 & 71.0 & 84.1 & 29.0 & 28.7 & $10: 32: 00 \mathrm{am}$ & $2 \mathrm{am}$ \\
\hline $16-31 \mathrm{Ja}$ & 24.5 & 19.7 & 7.6 & 4.6 & 64.7 & 85.5 & 19.2 & 29.8 & $10: 45: 07 \mathrm{am}$ & $6 \mathrm{am}$ \\
\hline 1-15 Febru & .5 & 32.7 & 7.3 & 5.9 & 58.9 & 85.1 & 16.5 & 25.9 & 11:04:16 am & $2 \mathrm{am}$ \\
\hline $16-28 \mathrm{o}$ & .6 & .6 & 1.9 & 9.6 & 6.0 & 73.0 & 22.6 & 17.5 & $11: 24$ & am \\
\hline 1-15 March & 27.6 & 29.6 & 11.6 & 12.9 & 62.8 & 64.0 & 18.2 & 17.66 & $11: 46: 48 \mathrm{am}$ & $6 \mathrm{am}$ \\
\hline 16-31 Marc & 30.3 & 28.2 & 12.8 & 11.7 & 55.3 & 67.3 & 13.6 & 18.2 & $12: 11: 26 \mathrm{pm}$ & $41 \mathrm{pm}$ \\
\hline 1-15 April & 28.1 & 34.3 & 12.3 & 15.3 & 45.3 & 63.1 & 13.4 & 10.1 & $12: 36: 16 \mathrm{pm}$ & $28 \mathrm{pm}$ \\
\hline 16-30 April & 34.9 & 27.6 & 14.6 & 16.9 & 39.7 & 59.6 & 7.8 & 8.4 & $12: 58: 00 \mathrm{pm}$ & $5 \mathrm{pm}$ \\
\hline 1-15 May & 34.6 & 38.1 & 18.1 & 19.7 & 49.5 & 47.4 & 13.1 & 9.1 & $13: 20: 00 \mathrm{pm}$ & $0 \mathrm{pm}$ \\
\hline 16-31 May & 39.8 & 38.0 & 22.0 & 19.7 & 44.6 & 55.5 & 12.3 & 10.0 & $13: 35: 55 \mathrm{pm}$ & $4 \mathrm{pm}$ \\
\hline 1-15 June & 37.8 & 44.1 & 21.5 & 24.0 & 60.3 & 41.6 & 16.6 & 6.6 & $13: 48: 24 \mathrm{pm}$ & $13: 48: 44 \mathrm{pm}$ \\
\hline 16-30 June & 38.0 & 41.5 & 22.4 & 24.8 & 63.1 & 59.6 & 15.4 & 12.6 & 13:46:19 pm & $13: 46: 30 \mathrm{pm}$ \\
\hline $1-15 \mathrm{Ju}$ & 38.1 & 39.6 & 23.0 & 24.1 & 72.2 & 58.4 & 17.4 & 16.6 & $13: 47: 44 \mathrm{pm}$ & $6 \mathrm{pm}$ \\
\hline 16-31 July & 41.3 & 38.7 & 23.5 & 23.5 & 51.4 & 65.9 & 9.5 & 16.0 & $13: 36: 04 \mathrm{pm}$ & $13: 35: 08 \mathrm{pm}$ \\
\hline
\end{tabular}

Source: Meteorological authority, Assiut, Egypt.

The total growing degree days GDD, (base $=7^{\circ} \mathrm{C}$ ) was calculated for each planting date according to Saeed and Francis (1984) as follows:

Total growing degree days $(\mathrm{GDD})=$

$\Sigma[(($ Maximum + Minimum temperature $) / 2)-7]$ where:

$7=$ Zero growth point from sowing date to third cut continuous to seed maturity, (Table $2)$. 
Table 2. Total growing degree day (GDD) for each planting date and season at Assiut where Egyptian clover trials were conducted.

\begin{tabular}{|l|c|c|}
\hline \multirow{2}{*}{ Planting date } & Total growing degree day from planting date until third cut \\
\cline { 2 - 3 } & $\mathbf{2 0 1 4 / 2 0 1 5}$ & $\mathbf{2 0 1 5 / 2 0 1 6}$ \\
\hline $15^{\text {th }}$ September & 1930 & 1960 \\
\hline $15^{\text {th }}$ October & 1625 & 1692 \\
\hline $15^{\text {th }}$ November & 1562 & 1625 \\
\hline $15^{\text {th }}$ December & 1767 & 1860 \\
\hline
\end{tabular}

\section{Statistical analysis:}

For forage yield and its components in each planting date over the three cuts. Separate as well as combined analysis of variance were performed for the data over the planting dates in each season and over two seasons according to Gomez and Gomez (1984), whenever the homogeneity of variances between planting dates and over two seasons was detected. Means were compared using L.S.D. test at 5\% level of probability.

\section{Stability analysis:}

Stability analysis was computed according to Tai (1971), where he suggested partitioning the genotype $\mathrm{x}$ environment interaction (GE) effect of the $i^{\text {th }}$ variety into two components $\left(\alpha_{i}\right.$ and $\left.\lambda_{i}\right)$. These estimates $\left(\alpha_{i}\right.$ and $\lambda_{i}$ ) were computed for each of the six varieties to compare the relative stability of varieties. The parameter $\alpha_{i}$ measures the linear response to the environmental effects and $\lambda_{i}$ parameter measures the deviation from linear response in terms of the magnitude of the error variance. The two components are defined as genotypic stability parameters. The values $(\alpha=-1$, $\lambda=1)$ will be referred as perfect stability. However, the values $(\alpha=0, \lambda=1)$ will be referred as average stability whereas the values $(\alpha>0$ and $\lambda=1)$ as below average stability. The hyperbola graph to test $\alpha$ 's statistics and the limits the confidence interval for $\lambda$ 's statistics were superimposed according to Tai (1971).

\section{Results and Discussion 1- Plant height:}

The combined analysis in Table 3 indicated that there was highly significant difference among sowing dates and varieties for plant height. The second sowing date (October $15^{\text {th }}$ ) gave the highest plant height in first, second and over two seasons, with significant differences among the four sowing dates (Table 4). The $15^{\text {th }}$ September sowing date gave the lowest plant height. This could be due to that the climatological conditions prevailing during this period favoured. These results are in agreement with those reported by Kandil and Shalaby (1985b) and Ramadan et al. (1994). Serw-1 variety significantly gave the tallest plant height, while, Local variety gave the shortest plant height in first, second and over two seasons. These results are in opposite with obtained by Ramadan et al. (1994) and El-Zanaty (2005). 
Table 3. Combined analysis of variance for forage yield traits of six Egyptian clover varieties under different sowing dates over two seasons.

\begin{tabular}{|l|c|c|c|c|c|}
\hline \multirow{2}{*}{ Source of variation } & \multirow{2}{*}{$\mathbf{d . f}$} & \multicolumn{4}{|c|}{ Mean squares } \\
\cline { 3 - 6 } & & Plant height (cm) & Leaf/stem ratio & Fresh forage yield & Dry forage yield \\
\hline Years (Y) & 1 & $699.7^{* *}$ & $71.19^{* *}$ & 583.4 & $88.3^{* *}$ \\
\hline Rep./Year & 6 & 31.3 & 22.54 & 288.2 & 1.28 \\
\hline Sowing dates (D) & 3 & $2296.8^{* *}$ & $79.62^{* *}$ & $32324.4^{* *}$ & $914.2^{* *}$ \\
\hline Y x D & 3 & $340.3^{* *}$ & 4.44 & $5340.3^{* *}$ & $115.9^{* *}$ \\
\hline Error (b) & 18 & 17.2 & 14.52 & 98.2 & 2.24 \\
\hline Varieties (V) & 5 & $74.0^{* *}$ & $104.42^{* *}$ & $1043.7^{* *}$ & $23.1^{* *}$ \\
\hline V x D & 15 & $18.6^{*}$ & $31.43^{* *}$ & $225.8^{* *}$ & $9.1^{* *}$ \\
\hline V x Y & 5 & 8.1 & 2.91 & 50.1 & $17.4^{* *}$ \\
\hline V x D x Y & 15 & $20.2^{*}$ & 3.93 & $188.3^{* *}$ & $18.8^{* *}$ \\
\hline Error c & 120 & 9.54 & 6.25 & 70.0 & 2.12 \\
\hline
\end{tabular}

Table 4. Average plant height (cm) of six Egyptian clover varieties as affected by different sowing dates in 2014/2015, 2015/2016 and over two seasons.

\begin{tabular}{|c|c|c|c|c|c|c|c|c|}
\hline \multirow[b]{2}{*}{ Season } & \multirow[b]{2}{*}{ Planting date } & \multicolumn{7}{|c|}{ Variety } \\
\hline & & Serw-1 & $\begin{array}{c}\text { Gem- } \\
\text { meiza-1 }\end{array}$ & Giza-6 & Sakha-4 & Helally & $\begin{array}{c}\text { Local } \\
\text { variety }\end{array}$ & Mean \\
\hline \multirow{5}{*}{$2014 / 2015$} & 15 Sept. & 84.2 & 82.7 & 85.7 & 76.2 & 81.2 & 77.2 & 81.2 \\
\hline & 15 Oct. & 95.1 & 92.2 & 93.1 & 89.8 & 95.5 & 93.3 & 93.2 \\
\hline & 15 Nov. & 93.5 & 85.6 & 86.6 & 85.9 & 86.6 & 87.0 & 87.6 \\
\hline & 15 Dec. & 88.6 & 86.4 & 88.1 & 89.7 & 86.7 & 83.3 & 87.1 \\
\hline & Mean & 90.4 & 86.7 & 88.0 & 85.4 & 87.5 & 85.2 & 87.3 \\
\hline \multicolumn{9}{|l|}{ LSD5\% for } \\
\hline \multicolumn{2}{|l|}{ Sowing dates (D) } & & & & & & & 3.01 \\
\hline \multicolumn{2}{|l|}{ Variety $(\mathrm{V})$} & & & & & & & 2.06 \\
\hline \multicolumn{2}{|l|}{ D x V } & & & & & & & 4.12 \\
\hline \multirow{5}{*}{$2015 / 2016$} & 15 Sept. & 72.7 & 70.8 & 74.7 & 70.7 & 73.6 & 72.7 & 72.5 \\
\hline & 15 Oct. & 92.9 & 94.0 & 91.7 & 92.1 & 94.0 & 90.7 & 92.6 \\
\hline & 15 Nov. & 93.6 & 87.9 & 88.0 & 91.0 & 90.9 & 85.7 & 89.5 \\
\hline & 15 Dec. & 80.2 & 79.6 & 81.4 & 75.0 & 79.5 & 79.8 & 79.2 \\
\hline & Mean & 84.9 & 83.0 & 84.0 & 82.2 & 84.5 & 82.3 & 83.4 \\
\hline \multicolumn{9}{|l|}{ LSD5\% for } \\
\hline \multicolumn{2}{|l|}{ Sowing dates (D) } & & & & & & & 2.71 \\
\hline \multicolumn{2}{|c|}{ Variety $(V)$} & & & & & & & 2.14 \\
\hline \multicolumn{2}{|l|}{ D x V } & & & & & & & -- \\
\hline \multirow{5}{*}{$\begin{array}{c}\text { Over two sea- } \\
\text { sons (Combined) }\end{array}$} & 15 Sept. & 78.5 & 76.7 & 80.2 & 73.5 & 77.4 & 77.3 & 76.9 \\
\hline & 15 Oct. & 94.0 & 93.1 & 92.4 & 90.9 & 94.8 & 92.0 & 92.9 \\
\hline & 15 Nov. & 93.6 & 86.8 & 87.3 & 88.5 & 88.8 & 86.4 & 88.6 \\
\hline & 15 Dec. & 84.4 & 82.7 & 84.7 & 82.4 & 83.1 & 81.5 & 83.1 \\
\hline & Mean & 87.65 & 84.83 & 86.21 & 83.83 & 86.09 & 83.72 & 85.3 \\
\hline LSD5\% for & & & & & & & & \\
\hline Sowing dates (D & D) & & & & & & & 1.78 \\
\hline Variety (V) & $=$ & & & & & & & 1.53 \\
\hline D X V & $=$ & & & & & & & 3.05 \\
\hline $\mathbf{V} \times Y$ & $=$ & & & & & & & -- \\
\hline D X Y & $=$ & & & & & & & 2.51 \\
\hline D x V x Y & $=$ & & & & & & & 4.32 \\
\hline
\end{tabular}

- F value not significant.

\section{2- Leaf/stem ratio:}

The results in Table 3 showed that sowing dates and varieties highly significantly affected leaf/stem ratio over two seasons. Comparisons among the four sowing dates showed that sowing date at September $15^{\text {th }}$ resulted in the highest leaf/stem ratio of $44.5,43.5$ and $44 \%$ in $2014 / 2015$, $2015 / 2016$ and over the two seasons, respectively (Table 5). Moreover, the results indicated that leaf/stem ratio decreased gradually, reached its lowest value at the fourth planting date (December $15^{\text {th }}$ ) in both seasons and over two seasons (Table 5). These 
results are in agreement with those obtained by Kandil and Shalaby (1985b). Comparison between the average leaf/stem ratio of the different varieties, it be concluded that Local variety produced the significantly highest leaf/stem ratio as compared with the other varieties in both seasons (Table 5). These results are in line with those obtained by Radwan et al. (2014).

\section{3- Seasonal fresh and dry forage yields:}

Data presented in Tables 6 and 7 indicate that seasonal fresh and dry forage yields significantly affected by sowing dates and varieties in each season and over seasons. The combined analysis of variance (Table 3 ) over seasons revealed that seasons had significant effect on seasonal dry forage yield. The results in Table 6 showed the maximum seasonal fresh forage yield/plot of 142.9 and 142.7 $\mathrm{kg} /$ plot was obtained from planting sown on November $15^{\text {th }}$ and October $15^{\text {th }}$ in $2014 / 2015$ and $2015 / 2016$ seasons, respectively. But, the maximum seasonal dry forage yield was obtained when sowing was performed at December $15^{\text {th }}$ in 2014/2015 and over both seasons. This may be due to the high temperature consequence the high dry matter percentage in cutting of this late planting date. These results are in contrary with that reported by El-Zanaty (2005) who found sowing on the $1^{\text {st }}$ November significant surpassed sowing on the $1^{\mathrm{st}}$ December on seasonal dry forage yield by 13.6 and $24.5 \%$ in the first and second seasons, respectively.

Table 5. Average leaf/stem ratio (\%) of six Egyptian clover varieties as affected by different sowing dates in 2014/2015, $2015 / 2016$ and over two seasons.

\begin{tabular}{|c|c|c|c|c|c|c|c|c|}
\hline \multirow{2}{*}{ Season } & \multirow{2}{*}{$\begin{array}{l}\text { Planting } \\
\text { date }\end{array}$} & \multicolumn{7}{|c|}{ Variety } \\
\hline & & Serw-1 & Gemmeiza-1 & Giza-6 & Sakha-4 & Helally & Local variety & Mean \\
\hline \multirow{5}{*}{$2014 / 2015$} & 15 Sept. & 43.34 & 43.27 & 42.82 & 45.84 & 42.01 & 49.50 & 44.46 \\
\hline & 15 Oct. & 37.22 & 42.92 & 42.38 & 42.98 & 42.03 & 44.53 & 42.01 \\
\hline & 15 Nov. & 41.02 & 40.93 & 42.82 & 43.50 & 42.66 & 43.45 & 42.39 \\
\hline & 15 Dec. & 40.05 & 43.85 & 39.80 & 42.70 & 42.24 & 43.41 & 42.00 \\
\hline & Mean & 40.40 & 42.74 & 41.95 & 43.75 & 42.23 & 45.22 & 42.71 \\
\hline \multicolumn{9}{|l|}{ LSD5\% for } \\
\hline \multicolumn{2}{|l|}{ Sowing dates (D) } & & & & & & & 1.32 \\
\hline \multicolumn{2}{|l|}{ Variety (V) } & & & & & & & 1.15 \\
\hline \multicolumn{2}{|l|}{ D X V } & & & & & & & 2.31 \\
\hline \multirow{5}{*}{$2015 / 2016$} & 15 Sept. & 42.19 & 42.99 & 41.22 & 45.10 & 37.67 & 51.84 & 43.50 \\
\hline & 15 Oct. & 37.06 & 41.84 & 42.33 & 42.50 & 42.14 & 42.98 & 41.47 \\
\hline & 15 Nov. & 39.81 & 40.76 & 41.20 & 40.83 & 41.23 & 41.97 & 40.96 \\
\hline & 15 Dec. & 38.33 & 41.95 & 35.68 & 40.25 & 41.13 & 43.04 & 40.06 \\
\hline & Mean & 39.34 & 41.88 & 40.10 & 42.17 & 40.54 & 44.95 & 41.49 \\
\hline \multicolumn{9}{|l|}{ LSD5\% for } \\
\hline \multicolumn{2}{|l|}{ Sowing dates (D) } & & & & & & & 1.90 \\
\hline \multicolumn{2}{|l|}{ Variety (V) } & & & & & & & 2.15 \\
\hline \multicolumn{2}{|l|}{ D x V } & & & & & & & 4.30 \\
\hline \multirow{5}{*}{$\begin{array}{l}\text { Over two seasons } \\
\text { (Combined) }\end{array}$} & 15 Sept. & 42.76 & 43.13 & 42.02 & 45.47 & 39.84 & 50.67 & 43.98 \\
\hline & 15 Oct. & 37.14 & 42.38 & 42.35 & 42.74 & 42.08 & 43.76 & 41.74 \\
\hline & 15 Nov. & 40.42 & 40.84 & 42.01 & 42.16 & 41.95 & 42.71 & 41.68 \\
\hline & 15 Dec. & 39.19 & 42.90 & 37.74 & 41.47 & 41.68 & 43.23 & 41.03 \\
\hline & Mean & 39.88 & 42.32 & 41.03 & 42.97 & 41.39 & 45.09 & 42.11 \\
\hline LSD5\% for & & & & & & & & \\
\hline Sowing dates (D) & $=$ & & & & & & & 1.63 \\
\hline Variety (V) & $=$ & & & & & & & 1.23 \\
\hline D X V & $=$ & & & & & & & 2.46 \\
\hline$V \times Y$ & $=$ & & & & & & & -- \\
\hline D x Y & $=$ & & & & & & & -- \\
\hline D x V x Y & $=$ & & & & & & & -- \\
\hline
\end{tabular}

- F value not significant. 
The two factors, sowing dates and date of the last cut, play a great role in plant development i.e. plant height leaf/stem ratio and consequently the fresh and dry forage yields. Over two seasons, no significant differences were noticed in seasonal dry forage yield between commercial varieties of berseem clover (Serw-1, Gemmeiza-1, Giza-6,
Sakha-4 and Helally). But significant differences were noticed between each of commercial cultivars with Local variety Tables 6 and 7. These results are in line with those reported by Ramadan et al. (1994) and ElZanaty (2005) reported that no different between Helally, Sakha-4, Sakha3 and Giza 15.

Table 6. Seasonal fresh forage yield/plot (kg) of six Egyptian clover varieties as affected by different sowing dates in 2014/2015, 2015/2016 and over two seasons.

\begin{tabular}{|c|c|c|c|c|c|c|c|c|c|}
\hline \multirow[b]{2}{*}{ Season } & \multirow{2}{*}{\multicolumn{2}{|c|}{$\begin{array}{l}\text { Planting } \\
\text { date }\end{array}$}} & \multicolumn{7}{|c|}{ Variety } \\
\hline & & & Serw-1 & Gemmeiza-1 & Giza-6 & Sakha-4 & Helally & $\begin{array}{c}\text { Local } \\
\text { variety }\end{array}$ & Mean \\
\hline \multirow{5}{*}{$2014 / 2015$} & \multicolumn{2}{|c|}{15 Sept. } & 77.3 & 103.2 & 95.7 & 92.1 & 89.7 & 84.4 & 90.4 \\
\hline & \multicolumn{2}{|c|}{15 Oct. } & 126.0 & 128.5 & 116.5 & 129.9 & 132.6 & 113.3 & 124.5 \\
\hline & \multicolumn{2}{|c|}{15 Nov. } & 157.3 & 140.7 & 143.5 & 143.9 & 143.2 & 128.5 & 142.9 \\
\hline & \multicolumn{2}{|c|}{15 Dec. } & 114.6 & 116.6 & 118.3 & 124.8 & 120.0 & 101.4 & 116.0 \\
\hline & \multicolumn{2}{|c|}{ Mean } & 118.7 & 122.3 & 118.5 & 122.7 & 121.4 & 106.9 & 118.4 \\
\hline \multicolumn{10}{|l|}{ LSD5\% for } \\
\hline \multicolumn{2}{|c|}{ Sowing dates (D) } & $=$ & & & & & & & 6.19 \\
\hline \multicolumn{2}{|c|}{ Variety $(\mathrm{V})$} & $=$ & & & & & & & 4.62 \\
\hline \multicolumn{2}{|l|}{ D $\times$ V } & $=$ & & & & & & & 9.24 \\
\hline \multirow{5}{*}{$2015 / 2016$} & \multicolumn{2}{|c|}{15 Sept. } & 61.9 & 71.5 & 62.1 & 63.5 & 75.3 & 67.5 & 67.0 \\
\hline & \multicolumn{2}{|c|}{15 Oct. } & 139.5 & 138.0 & 149.3 & 150.3 & 155.5 & 123.8 & 142.7 \\
\hline & \multicolumn{2}{|c|}{15 Nov. } & 125.3 & 135.0 & 116.5 & 131.0 & 127.0 & 105.0 & 123.3 \\
\hline & \multicolumn{2}{|c|}{15 Dec. } & 119.3 & 130.0 & 129.3 & 129.3 & 127.3 & 125.8 & 126.8 \\
\hline & \multicolumn{2}{|c|}{ Mean } & 111.5 & 118.6 & 114.3 & 118.5 & 121.3 & 132.3 & 115.0 \\
\hline \multicolumn{10}{|l|}{ LSD5\% for } \\
\hline \multicolumn{2}{|c|}{ Sowing dates (D) } & $=$ & & & & & & & 8.78 \\
\hline \multicolumn{2}{|l|}{ Variety (V) } & $=$ & & & & & & & 2.15 \\
\hline \multicolumn{2}{|l|}{ D $\times V$} & $=$ & & & & & & & 4.29 \\
\hline \multirow{5}{*}{$\begin{array}{l}\text { Over two sea- } \\
\text { sons (Com- } \\
\text { bined) }\end{array}$} & \multicolumn{2}{|c|}{15 Sept. } & 69.6 & 87.4 & 78.9 & 77.8 & 82.5 & 75.9 & 78.7 \\
\hline & \multicolumn{2}{|c|}{15 Oct. } & 132.8 & 133.3 & 132.9 & 140.1 & 144.0 & 118.5 & 133.6 \\
\hline & \multicolumn{2}{|c|}{15 Nov. } & 141.3 & 137.9 & 130.0 & 137.5 & 135.1 & 116.8 & 133.1 \\
\hline & \multicolumn{2}{|c|}{15 Dec. } & 116.9 & 123.3 & 123.8 & 127.0 & 123.6 & 113.6 & 121.4 \\
\hline & & & 115.2 & 120.5 & 116.4 & 120.6 & 121.3 & 106.2 & 116.7 \\
\hline LSD5\% for & & & & & & & & & \\
\hline Sowing dates & & $=$ & & & & & & & 4.25 \\
\hline Variety (V) & & $=$ & & & & & & & 4.12 \\
\hline D x V & & $=$ & & & & & & & 8.24 \\
\hline$V \times Y$ & & $=$ & & & & & & & -- \\
\hline D x Y & & $=$ & & & & & & & 6.01 \\
\hline$D \times V \times Y$ & & $=$ & & & & & & & 11.65 \\
\hline
\end{tabular}

- F value not significant. 
Table 7. Seasonal dry forage yield/plot $(\mathrm{kg})$ of six Egyptian clover varieties as affected by different sowing dates in $2014 / 2015,2015 / 2016$ and over two seasons.

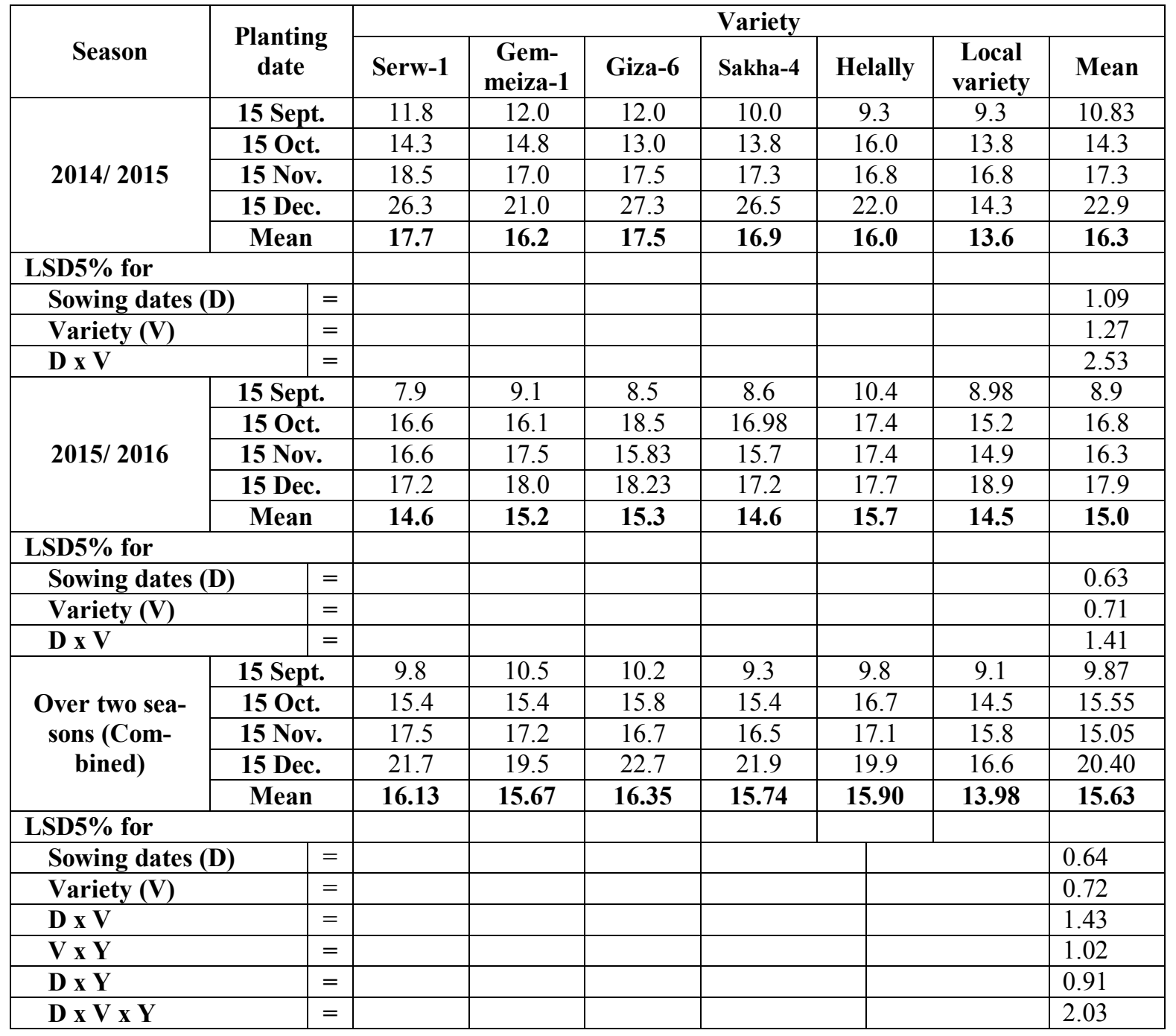

Stability analysis:

\section{1-Stability analysis for forage yield and its components:}

Analysis of variance across varieties and environments indicated that the environments, varieties and varieties $\mathrm{x}$ environments (GE) interaction were highly significant for plant height, leaf/stem ratio and dry forage yield, except the environments effect for leaf/stem ratio was significant only (Table 8). The environment mean square was significant indicating that the four planting dates in the two seasons provided a sufficient range of environments, and hence the validating of environmental requirements suggested by Tai (1971) were fulfilled. The results are in broad agreement with reported by Bakheit (1985), Khatri et al. (1991), Bakheit and El-Hinnawy (1993), and AbdelGalil et al. (2007).

According to Tai's theory, the variety by environment interaction is partitioned into two components: $\alpha$ which measures the linear response to environmental effect and $\lambda$ which measures the deviation from the linear response. The genotypic stability 
parameters were determined $(\overline{\mathrm{X}}, \alpha$ and $\lambda$ ) for all varieties for plant height, leaf/stem ratio and dry forage yield and presented in Table 9.

According to this method, the values $(\alpha=0-1, \lambda=1)$ refer to perfect stability, while a variety that has only average stability might have an estimate of $\alpha=0.0$ and $\lambda=1$. The varieties different in the amount of deviation from the linear response $(\lambda)$ and to a less extent in the response $(\alpha)$ for dry forage yield. This variation suggested that the relatively unpredictable components of the genotype $\mathrm{x}$ environment interaction variance may be more important than the relatively predictable component of variation for those varieties which showed dif- ferent degree of stability as mentioned by Bakheit (1985). The variety Sakha-4 was significant value for plant height, while Giza-6 variety was significant value for leaf/stem ratio. But the varieties Serw-1, Giza6 , Sakha-4 and local variety were significant values for dry forage yield. Therefore, they were considered to be unstable (Table 9 and Fig. $1)$.

Also, the average stability region involved Gemmeiza-1, Giza-6, Serw- 1 and Helally varieties for plant height, Gemmeiza-1, Serw-1 and Local variety varieties for leaf stem/ratio and Gemmeiza and Helally varieties for dry forage yield.

Table 8. Stability analysis of variance for plant height, leaf/stem ratio \% and dry forage yield of six Egyptian clover varieties under different environments.

\begin{tabular}{|l|c|c|c|c|}
\hline \multirow{2}{*}{ Source of variation } & \multirow{2}{*}{ d.f } & \multicolumn{3}{|c|}{ Mean squares for } \\
\cline { 3 - 5 } & & $\begin{array}{c}\text { Plant height } \\
\text { (cm) }\end{array}$ & $\begin{array}{c}\text { Leaf/stem ratio } \\
(\%)\end{array}$ & $\begin{array}{c}\text { Dry forage yield } \\
\text { (kg/plot) }\end{array}$ \\
\hline Environment (E) & 7 & $1230.2^{* *}$ & $46.20^{*}$ & $454.07^{* *}$ \\
\hline Rep./Envir. & 24 & 20.70 & 16.52 & 2.01 \\
\hline Varieties (V) & 5 & $73.97^{* *}$ & $104.42^{* *}$ & $23.06^{* *}$ \\
\hline V x E & 35 & $17.76^{* *}$ & $15.57^{* *}$ & $14.46^{* *}$ \\
\hline Error & 120 & 9.54 & 6.25 & 2.12 \\
\hline
\end{tabular}

$*, * *$ Significant at 0.05 and 0.01 level of probability, respectively.

Table 9. Mean performance over eight environment $(\bar{X})$ and stability parameter $(\alpha, \lambda)$ of six Egyptian clover varieties for plant height, leaf/stem ratio and dry forage yield.

\begin{tabular}{|l|c|c|c|c|c|c|c|c|c|}
\hline \multirow{2}{*}{ Traits } & \multicolumn{2}{|c|}{ Plant height (cm) } & \multicolumn{3}{c|}{ Leaf/stem ratio (\%) } & \multicolumn{2}{c|}{ Dry forage yield (kg/plot) } \\
\cline { 2 - 10 } & $\overline{\mathrm{X}}$ & $\boldsymbol{\alpha}$ & $\boldsymbol{\lambda}$ & $\overline{\mathrm{X}}$ & $\boldsymbol{\alpha}$ & $\boldsymbol{\lambda}$ & $\overline{\mathrm{X}}$ & $\boldsymbol{\alpha}$ & $\boldsymbol{\lambda}$ \\
\hline Serw-1 & 87.7 & 0.10 & 1.78 & 39.88 & 0.40 & 1.56 & 16.13 & 0.21 & $2.47^{*}$ \\
\hline Gemmeiza-1 & 84.8 & 0.02 & 0.92 & 42.32 & -0.93 & 0.43 & 15.67 & -0.16 & 1.18 \\
\hline Giza-6 & 26.2 & -0.20 & 0.99 & 41.03 & 0.16 & $2.58^{*}$ & 16.35 & 0.25 & $4.22^{*}$ \\
\hline Sakha-4 & 83.8 & 0.14 & $3.06^{*}$ & 42.97 & 0.55 & -0.02 & 15.74 & 0.24 & $2.40^{*}$ \\
\hline Helally & 86.1 & 0.03 & 0.41 & 41.39 & -1.93 & 0.58 & 15.95 & -0.11 & 2.00 \\
\hline Local variety & 83.7 & -0.08 & 1.99 & 45.09 & 1.75 & 2.08 & 13.98 & -0.43 & $12.01^{*}$ \\
\hline
\end{tabular}

* Value greater than Fa value derived from $\mathrm{F}$ table with $\mathrm{n}_{1}=6, \mathrm{n}_{2}=120$ and $\mathrm{a}=0.05$ 

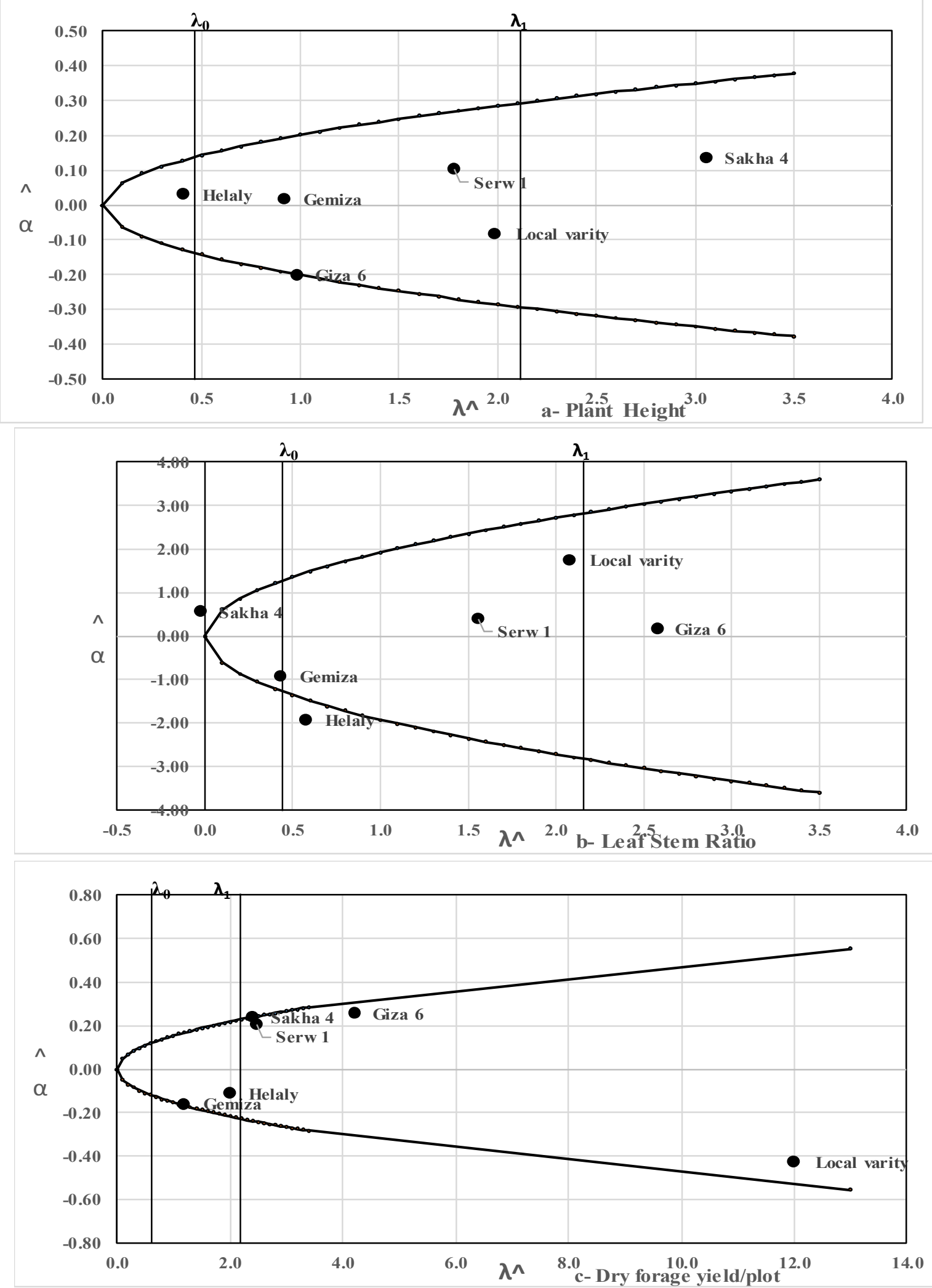

Fig. 1. Distribution of estimates of genotypes stability parameter $(\alpha \& \lambda)$ for plant height, leaf stem ratio and dray forage yield/plot of six Egyptian clover varieties. 


\section{References}

Abdel-Galil, M.M., W.M. Shaarawy, A.A. Helmy and M.A. El-Nahrawy (2007). Yield potential and stability performance of sixteen Egyptian clover genotypes grown under different environments. Assiut J. Agric. Sci., 38: 1-13.

B.A.S. (2016). Bulletin of the Agricultural Statistics (2014/2015), pp. 55-57.

Bakheit, B.R. (1985). Genotypic stability of some multi-cut Egyptian clover (Trifolium alexandrinum) genotypes. Assiut J. Agric. Sci., 16: 2137.

Bakheit, B.R. and H.H. El-Hinnawy (1993). Performance and stability for forage yield in Egyptian clover genotypes (Trifolium alexandrinum L.) under drought conditions. Forage Res., 19: 261-266.

El-Zanaty, I.A. (2005). Influence of sowing date on forage and seed yield on some new varieties of Egyptian clover. Minia J. Agric. Res. Dev., 25: 757-780.

Gomez, K.A. and A.A. Gomez (1984). Statistical Procedures for Agricultural Research. 2 ${ }^{\text {nd }}$ Edn., John Wiley and Sons Inc., New York, USA., ISBN: 139780471879312, pp: 13-175.

Graves, W.L., W.A. Williams and C.D. Thomsen (1996). Berseem clover: A winter annual forage for California agriculture. University of California Division of Agriculture and Natural Resources, Publication No. 21536, pp: 12.

Kandil, A.A. and A.E. Sharief (2016). New approach for increasing Egyptian clover productivity in North Delta. STC Agriculture and Natural Resources, 2: 8-27.

Kandil, A.A. and Y.Y. Shalaby (1985b). Effect of planting dates, seeding methods and plant density on Egyptian clover seed yield. 1Yield components. The $2^{\text {nd }}$ Conf. on Agric. Bot. Sci., 21-24 ${ }^{\text {th }}$ Sept. 1985, pp. 221-231, Mansoura Univ., Fac. of Agric., Dept. of Agric., Botany.

Khatri, R.S., D.S. Jatasra and B.S. Mehla (1991). Phenotypic stability for fodder yield in berseem (Trifolium alexandrium L.). Forage Res., 17: 21-24.

Radwan, M.S.; K.I. Abdel-Gawad; Hoda I.M. Ibrahim; M.Th. Hassan and W.M. El-Debeikly (2014). The effect of planting density on estimates of genetic variance heritability and correlation between traits of berseem clover. Egypt. J. Plant Breed., 18: 389-403.

Ramadan, G.A.; H.A. Boraei and M.E. Haggag (1994). Evaluation of new selected varieties of Egyptian clover (Trifolium alexandrinum L.) to forage yield quality and quantity and for susceptibility to the Egyptian alfalfa weevil (Hypera brunneipennis Both.). J. Agric. Sci. Mansoura Univ., 19: 423-438.

Saeed, M. and C.A. Francis (1984). Association of weather variables with genotype $\mathrm{x}$ environment interaction in grain sorghum. Crop Sci., 24: 13-16.

Tai, G.C.C. (1971). Genotypic stability analysis and its application to potato regional trials. Crop Sci., 11: 184-190.

Usmani-Khail, M.U., A.H. Ansari, L.S. Rajput, F.C. Oad, N.L. Oad and G.N. Sohu (2001). Effect of agronomic practices on fresh forage and seed yield of berseem Trifolium alexandrium L. J. Applied Sci., 1: 359-362. 


\section{ثبات المحصول العلفي لبعض التراكيب الور اثية تحت اختلاف مواعيد الزراعة} باهي راغب بخيث، المهدي عبد المطلب طعيمه، أسماء علي محمد، فتحي محمد فتحي قسم المحاصيل - كلية الزر اعة - جامعة أسيوط

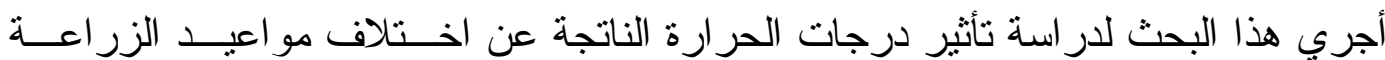

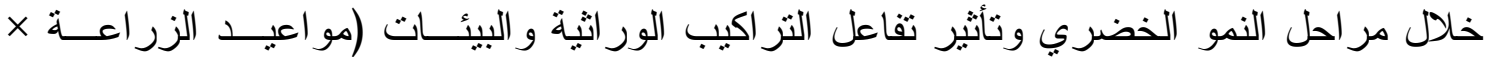

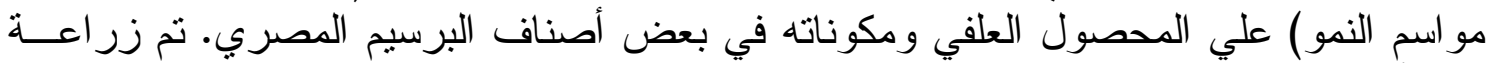

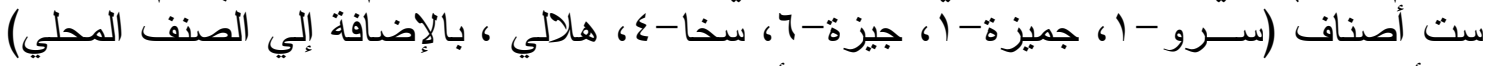

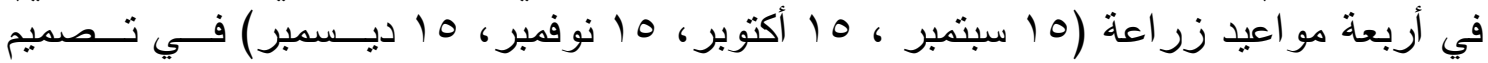

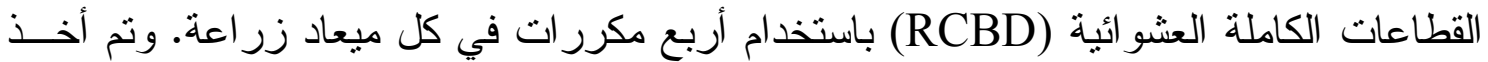

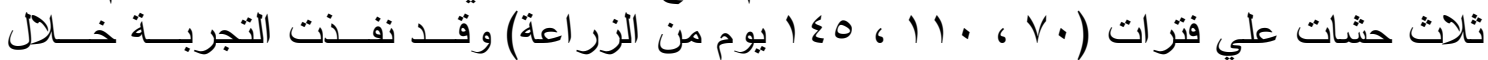

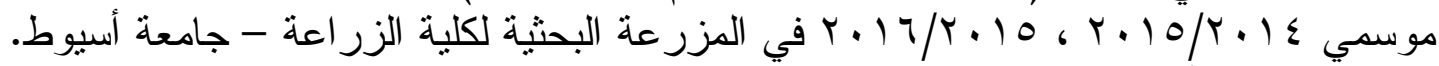

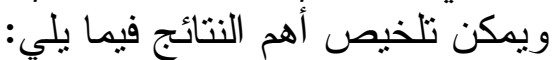

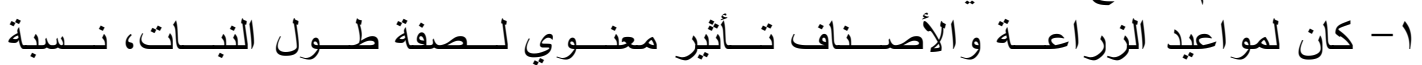

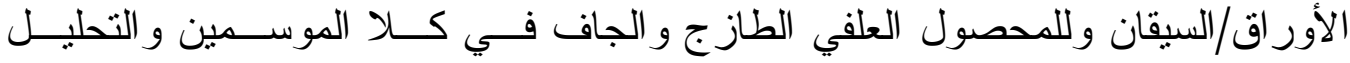
المشترك.

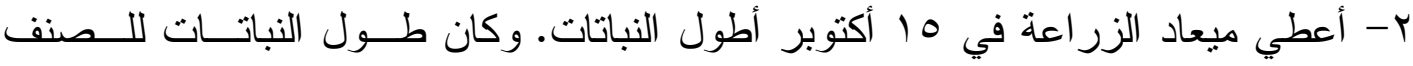

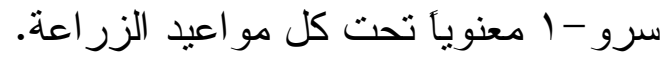

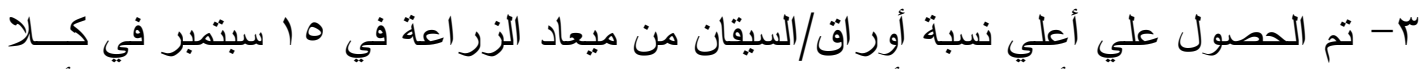

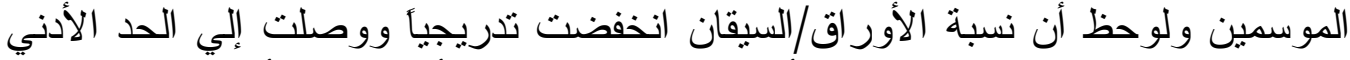

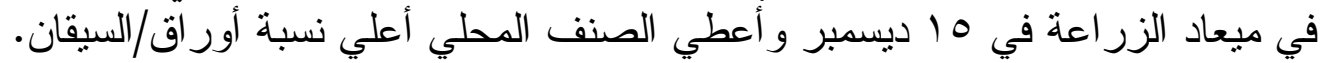

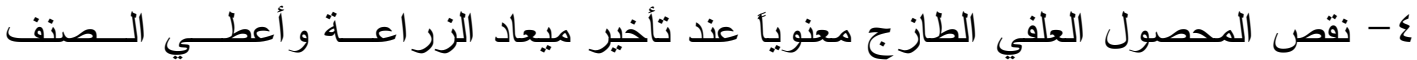

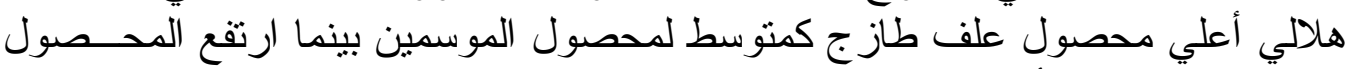

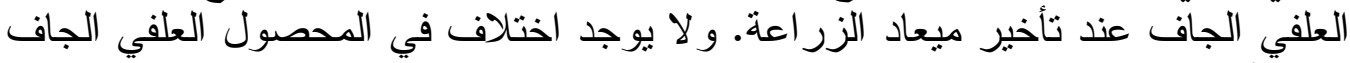
بين الأصناف التجارية.

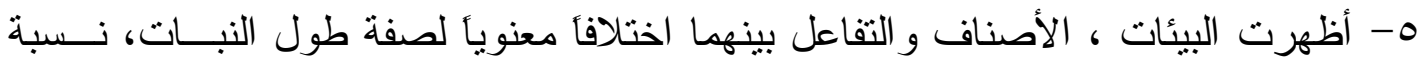

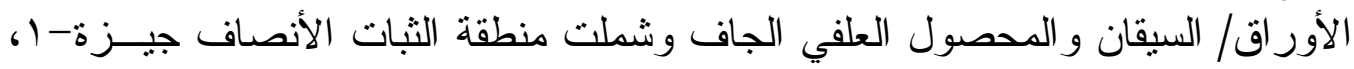

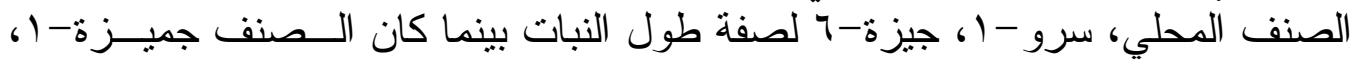

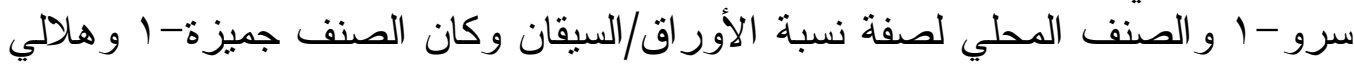
لصفة المحصول العلفي الَّاف. 